\title{
Regulation of histone methylation by automethylation of PRC2
}

\author{
Xueyin Wang, ${ }^{1,2,3,5}$ Yicheng Long, ${ }^{1,2,5}$ Richard D. Paucek, ${ }^{1,2,4}$ Anne R. Gooding, ${ }^{1,2}$ Thomas Lee, $^{2}$ \\ Rachel M. Burdorf, ${ }^{1,2}$ and Thomas R. Cech $^{1,2}$ \\ ${ }^{1}$ Howard Hughes Medical Institute, University of Colorado at Boulder, Boulder, Colorado 80309, USA; ${ }^{2}$ Department of Chemistry \\ and Biochemistry, BioFrontiers Institute, University of Colorado at Boulder, Boulder, Colorado, 80309 USA
}

\begin{abstract}
Polycomb-repressive complex 2 (PRC2) is a histone methyltransferase that is critical for regulating transcriptional repression in mammals. Its catalytic subunit, EZH2, is responsible for the trimethylation of $\mathrm{H} 3 \mathrm{~K} 27$ and also undergoes automethylation. Using mass spectrometry analysis of recombinant human PRC2, we identified three methylated lysine residues (K510, K514, and K515) on a disordered but highly conserved loop of EZH2. Methylation of these lysines increases PRC2 histone methyltransferase activity, whereas their mutation decreases activity in vitro. De novo histone methylation in an EZH2 knockout cell line is greatly impeded by mutation of the automethylation lysines. EZH2 automethylation occurs intramolecularly (in cis) by methylation of a pseudosubstrate sequence on a flexible loop. This posttranslational modification and cis regulation of PRC2 are analogous to the activation of many protein kinases by autophosphorylation. We propose that EZH2 automethylation allows PRC2 to modulate its histone methyltransferase activity by sensing histone $\mathrm{H} 3$ tails, SAM concentration, and perhaps other effectors.
\end{abstract}

[Keywords: CRISPR; epigenetics; H3K27me3; lysine methylation; pseudosubstrate]

Supplemental material is available for this article.

Received May 15, 2019; revised version accepted July 30, 2019.

Protein phosphorylation is the most common posttranslational modification (PTM), and autophosphorylation is an extensively studied process of fundamental importance to protein kinases and signal transduction (Krebs et al. 1959; Newton 2003). Autophosphorylation can be intermolecular (a protein kinase phosphorylates another molecule of the same type) or intramolecular (a protein kinase molecule adds a phosphate to itself). In contrast to autophosphorylation, automethylation of proteins has been the subject of only a handful of reports (Piao et al. 2016; Iglesias et al. 2018). This is in spite of the fact that methylation of histone and nonhistone proteins is appreciated to be a major PTM critical for the regulation of gene expression and epigenetic inheritance (Long et al. 2017b). Here we aim to enhance this meager body of information by investigating the mechanism and function of automethylation of the epigenetic silencing complex Polycombrepressive complex 2 (PRC2).

Many protein methyltransferases catalyze the transfer of methyl groups from $S$-adenosyl-L-methionine (SAM) to the $\varepsilon$-amino group of lysine side chains. One major group contains a catalytic SET domain, a $\beta$-sheet structure with a catalytic tyrosine residue at the center (Trievel

Present addresses: ${ }^{3}$ A2 Biotherapeutics Inc, Agoura Hills, CA 90301, USA; ${ }^{4}$ David Geffen School of Medicine, University of California at Los Angeles, Los Angeles, CA 90095, USA.

${ }^{5}$ These authors contributed equally to this work.

Corresponding author: thomas.cech@colorado.edu

Article published online ahead of print. Article and publication date are online at http://www.genesdev.org/cgi/doi/10.1101/gad.328849.119. et al. 2002). One prominent lysine methyltransferase is PRC2, which is the sole enzymatic complex capable of catalyzing deposition of methyl groups onto Lys27 of histone H3 (Davidovich and Cech 2015). This activity is vital for the repression of genes in mammalian cells in processes such as cellular differentiation and embryonic development. Recently, it was discovered that PRC2 can regulate transcription by methylating nonhistone targets as well (Ardehali et al. 2017).

A surge of findings in the last decade has suggested involvement of PRC2 in a number of disease processes, including multiple types of cancer, tumor immunity, cardiac hypertrophy, Huntington's disease, and latency of viral infections, including HIV and HSV (Cliffe et al. 2009; Wang and Davidovich 2017; Paucek et al. 2019|. Accordingly, understanding how PRC2 is regulated holds the potential to translate into clinical application. The regulation of PRC2 has so far been known to occur through the recruitment of various accessory proteins and binding of RNA (Davidovich et al. 2013; Davidovich and Cech 2015; Poepsel et al. 2018; Youmans et al. 2018; Zhang et al. 2019). For instance, the accessory protein JARID2 has been shown to substantially increase PRC2 enzymatic activity (Li et al. 2010; Sanulli et al. 2015). Furthermore,

(c) 2019 Wang et al. This article is distributed exclusively by Cold Spring Harbor Laboratory Press for the first six months after the full-issue publication date (see http://genesdev.cshlp.org/site/misc/terms.xhtml). After six months, it is available under a Creative Commons License (Attribution-NonCommercial 4.0 International), as described at http://creativecommons.org/licenses/by-nc/4.0/. 
RNA molecules containing short stretches of guanines bind to PRC2 (Wang et al. 2017a) and inhibit its histone methyltransferase (HMTase) activity (Cifuentes-Rojas et al. 2014; Kaneko et al. 2014) by inhibiting PRC2 binding to nucleosomes (Beltran et al. 2016) -more specifically, the linker regions of nucleosomes (Wang et al. 2017b).

However, other points of regulation are likely to exist because PRC2 is known to undergo a variety of covalent posttranslation modifications, including phosphorylation, sumoylation, and methylation (Morey and Helin 2010; Sanulli et al. 2015). Indeed, PRC2 has long been thought to automethylate (Müller et al. 2002; Whitcomb et al. 2012; Sanulli et al. 2015; Ardehali et al. 2017; Wang et al. 2017b). However, neither the mechanism nor the function of PRC2 automethylation has been described.

We interrogated PRC2 automethylation and found that it has substantial implications for the regulation of epigenetic gene silencing. Using biochemical and mass spectroscopic (MS) approaches, we found that PRC2 is automethylated at three lysines on a novel and evolutionarily conserved flexible loop in EZH2. Furthermore, methylation of this loop was found to substantially stimulate PRC2-catalyzed H3K27 methylation in vitro and in cells. We also determined that PRC2 automethylation occurs in an intramolecular (cis) reaction. Taken together, our data reveal that automethylation of a disordered loop in EZH2 stimulates PRC2 and promotes deposition of histone methylation marks. This study suggests a regulatory function for PRC2 automethylation in modulating its histone methyltransferase activity in response to $\mathrm{H} 3$ and SAM concentration and perhaps other effectors.

\section{Results}

\section{Human PRC2 is methylated on the EZH2 component}

We observed PRC2 automethylation during typical HMTase assays using purified recombinant human PRC2. Automethylation appeared to occur on the EZH2 and/or SUZ12 subunits (Fig. 1A), which have similar molecular weights and therefore run as one overlapping band on SDS-PAGE. To unambiguously identify which subunit is methylated, we used PRC2 complexes in which a single subunit was MBP-tagged and therefore had retarded electrophoretic mobility. As shown in Figure 1B, EZH2, the catalytic subunit, is the main target of automethylation.

\section{Automethylation occurs at three sites on a conserved flexible loop of EZH2}

To determine which EZH2 amino acid residues were being methylated, we incubated PRC2 with $10 \mathrm{mM}$ SAM (unlabeled) under standard HMTase assay conditions, then subjected the protein mixtures to rare cutting protease digestion, and, lastly, analyzed the samples using MS (Fig. 2). To avoid potential peptide bias introduced by protease digestion, independent MS experiments were performed using either Arg-C or chymotrypsin as protease.

The additional mass due to a single methyl modification is 14 AMU. By comparing peptide masses between

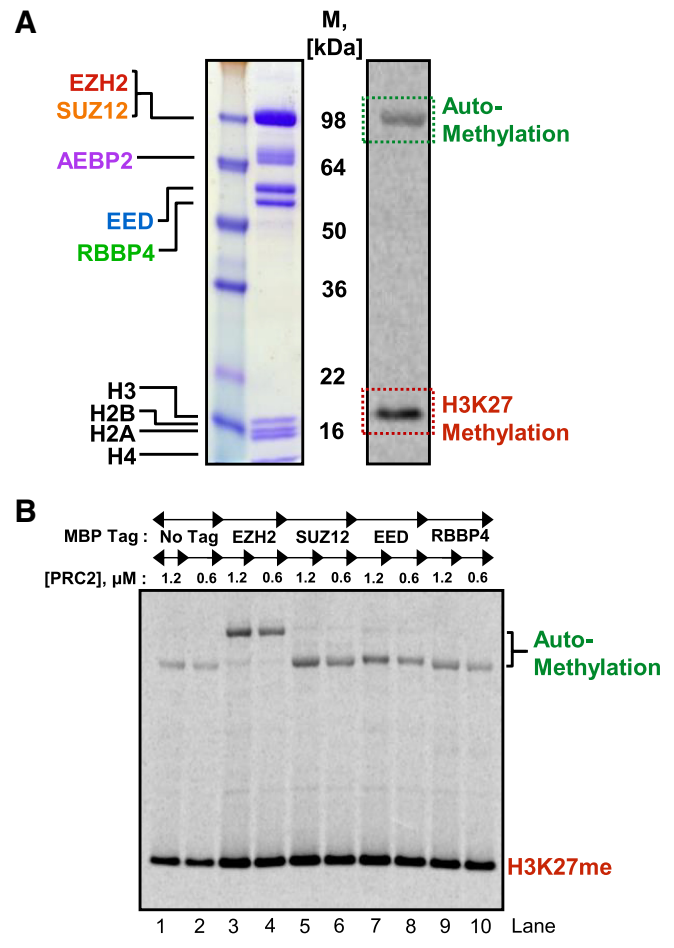

Figure 1. The EZH2 component of PRC2 is methylated. (A) HMTase assays showing PRC2 enzymatic activity to mononucleosome and automethylation of PRC2. (B) HMTase assays showing that EZH2 is the subunit methylated by PRC2. HMTase assays were performed with one subunit containing an uncleavable MBP tag and mononucleosome in the presence of cofactor ${ }^{14} \mathrm{C}-\mathrm{SAM}$.

an unmethylated PRC2 sample (Fig. 2B) and a methylated PRC2 sample (Fig. 2C), automethylation marks were mapped to three lysine residues in EZH2 that exist in close proximity to one another: K510, K514, and K515 (Fig. 2D). The expected theoretical masses of methyl-modified peptides were in agreement with experimental observations (Fig. 2D). Importantly, MS experiments using either Arg-C or chymotrypin identified the same methylation sites.

Automethylation was increased in the presence of substrate H3. Three independent MS experiments were performed on samples of either PRC2, PRC2 + SAM, or PRC2 + SAM + H3. K510 was mostly monomethylated, as illustrated in Figure 2E (left). The data revealed that (1) a fraction of PRC2 (7\%) was already automethylated at $\mathrm{K} 510$ in the recombinant protein purified from insect cells, (2) the incubation of SAM with PRC2 in vitro increased the abundance of monomethylated and dimethylated peptides (from $7 \%$ to $20 \%$ ), and (3) the addition of $\mathrm{H} 3$ to a mixture of SAM and PRC2 further increased the abundance of monomethylated and dimethylated peptides (from $20 \%$ to $50 \%$ ). The third finding might suggest that upon binding to $\mathrm{H} 3$, PRC2 may undergo a conformational change that favors the automethylation of EZH2.

Because K514 and K515 are adjacent, it has been difficult to determine their methylation distribution. For 
A

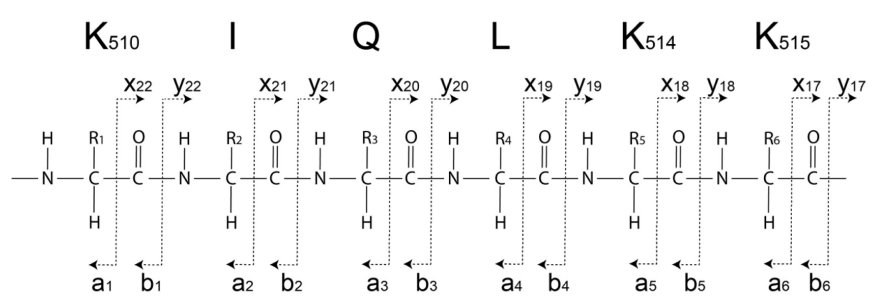

B
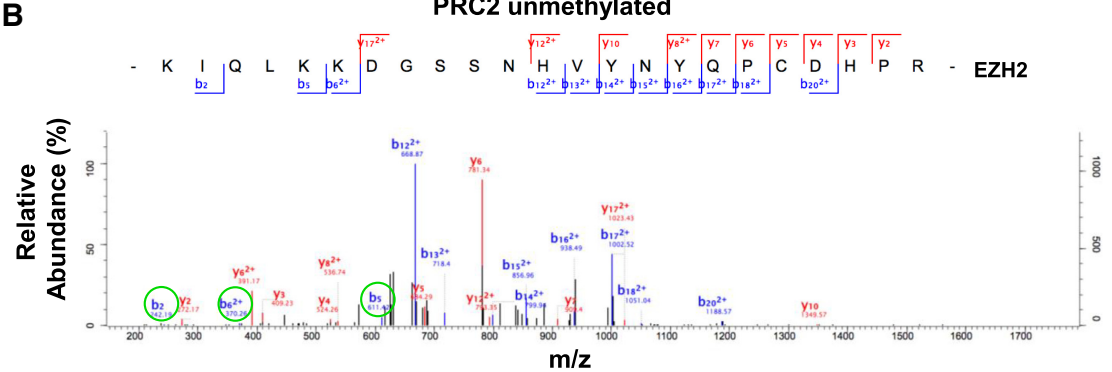

C

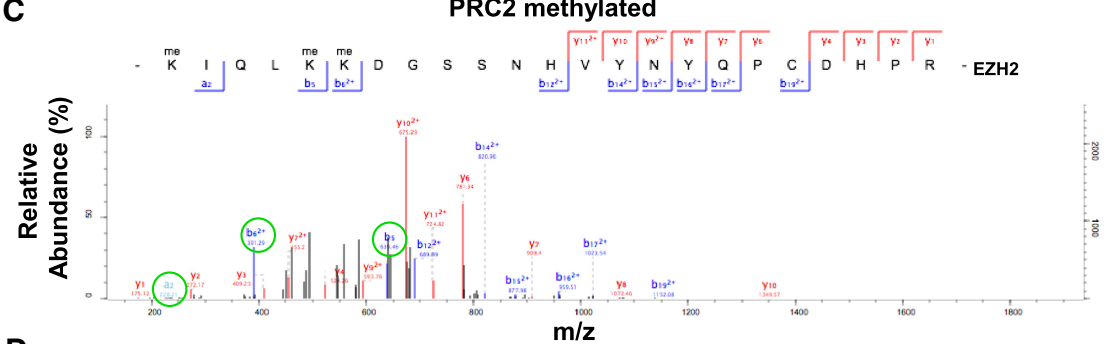

D

Methylation Site-determining ions ${ }^{a}$

\begin{tabular}{|c|c|c|c|c|c|}
\hline & Ion & Obs. & $\mathrm{m} / \mathrm{z}$ difference & m difference & Numbers of methylation sites \\
\hline \multirow{3}{*}{$\begin{array}{c}\text { PRC2 } \\
\text { unmethylated }\end{array}$} & $b_{2}$ & 242.19 & N/A & N/A & N/A \\
\hline & $b_{5}$ & 611.42 & N/A & N/A & N/A \\
\hline & $b_{6}{ }^{2+}$ & 370.26 & N/A & N/A & N/A \\
\hline \multirow{3}{*}{$\begin{array}{c}\text { PRC2 } \\
\text { methylated }\end{array}$} & $a_{2}$ & 228.21 & $14^{\mathrm{b}}$ & $14^{b}$ & 1 \\
\hline & $b_{5}$ & 639.46 & 28 & 28 & 2 \\
\hline & $b_{6}^{2+}$ & 391.29 & 21 & 42 & 3 \\
\hline
\end{tabular}

a Ion=fragment ion, Obs.=Observed

b $14=228.21+28$ ( $m$ difference between a2 and b2 ions) -242.19

E
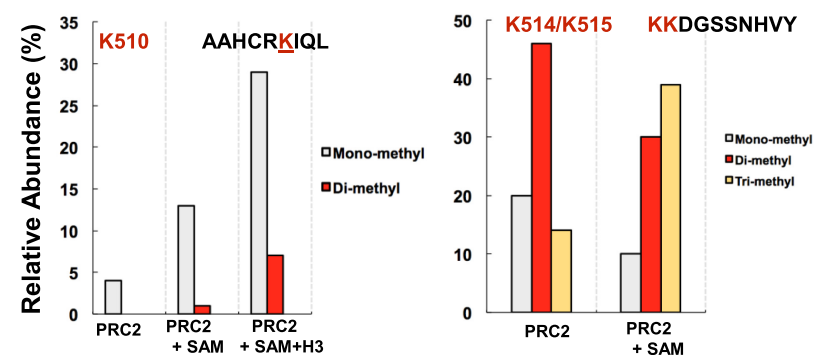

Figure 2. Identification of the key residues automethylated by PRC2 using LC-MS/ MS. (A) An example of annotation of fragmented ions of MS/MS for a 6-mer peptide (K510 to K515). Predicted ions are labeled with $a, b, x$, and $y$, and the cleavage sites are marked with dashed lines. Note that the b2 ion is $28 \mathrm{Da}$ (one carbon and one oxygen) heavier than the a2 ion. (B) MS/MS spectra of an unmethylated PRC2 peptide (residues 510-532). (C) MS/MS spectra of the same peptide showing that each of K510, K514, and K515 residues was monomethylated during HMTase assays. Methylation sites were supported by $\mathrm{a}$ and $\mathrm{b}$ ions circled in green. $(D)$ A summary of $\mathrm{a}$ and $\mathrm{b}$ ions supporting methylation sites in PRC peptide (amino acids 510-532). Note that monomethylation on $\mathrm{K} 510$ was supported by the a2 ion. (E, left) Relative abundance of methylated isoforms at the K510 site. (Right) Relative abundance of methylated isoforms of a peptide that contains K514 and $\mathrm{K} 515$. example, the chymotryptic peptide KKDGSSNHVY was observed to be trimethylated (Fig. 2E, right), but we could not distinguish $\mathrm{K}(\mathrm{me} 2) \mathrm{K}(\mathrm{me}) \mathrm{DGSSNHVY}$ from $\mathrm{K}(\mathrm{me}) \mathrm{K}$ (me2)DGSSNHVY, and trimethylation of K514 or K515 would also result in the same $\mathrm{m} / \mathrm{z}$ for the peptide. Other PTMs (Morey and Helin 2010) reported to decorate PRC2, such as phosphorylation and sumoylation, were not found in our MS analysis of recombinant PRC2 expressed in insect cells.
The three methylation sites (K510, K514, and K515) exist on a disordered loop of EZH2 (i.e., not seen in the crystal structures [Justin et al. 2016] or in the cryo-EM reconstructions of PDB: 6C23 and 6C24 [Kasinath et al. 2018]). This disordered loop in EZH2 (referred to here as the "methylation loop") extends from position 474 at the end of the SANT2 domain to position 528 at the beginning of the CXC domain (Fig. 3A). The methylation loop shows striking sequence conservation not only between 
PRC2 automethylation regulates histone methylation

A

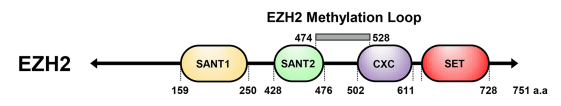

B

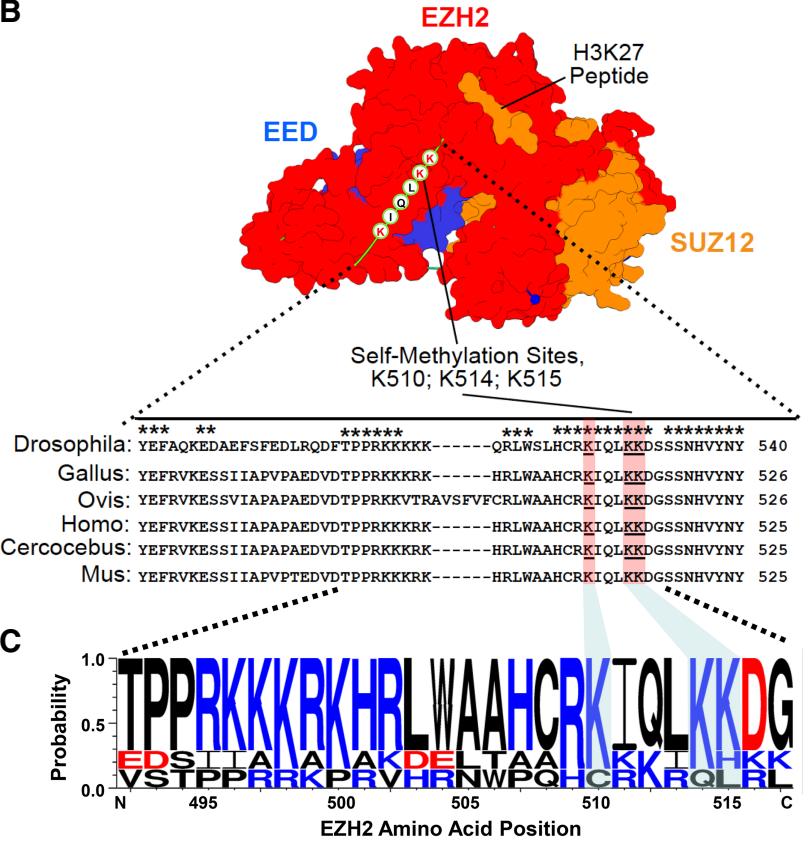

Figure 3. Key methylated residues in PRC2 map to a flexible and conserved charged loop in EZH2. (A) The EZH2 methylation loop overlaps the regions flanking the SANT2 and CXC domains. $(B)$ The three methylated lysines (highlighted) are conserved as shown in sequence alignment. Surface representation of crystal structure of a PRC2 subcomplex from PDB: 5HYN. (C) Sequence alignments of species shown in $B$ show extensive conservation of a basic motif in EZH2. Blue amino acids indicate basic residues, and red amino acids indicate charged residues. Methylation sites at K510, K514, and K515 are highlighted.

human and other vertebrate homologs but also with Drosophila melanogaster (Fig. 3B). Notably, the three automethylated lysines are well conserved.

Another noteworthy property of the methylation loop is the large cluster of positive charges. This is illustrated in Figure $3 \mathrm{C}$ by the sequence logo representation of a selected region (residues 490-520) of the methylation loop, where the blue letters indicate positively charged residues. Given the phylogenetic conservation of the methylation sites and charged residues in the EZH2 methylation loop, we hypothesized that this region may serve regulatory roles analogous to disordered loops seen in many protein kinases; phosphorylation causes a conformational change of the loop that allows substrate to bind (Hurley et al. 1990). The regulatory role of a different portion of this disordered region of EZH2 (489-494) by interacting with RNA has also been demonstrated recently (Long et al. 2017a).

Confirmation that EZH2 automethylation occurs in vivo has been provided by Reinberg and colleagues (see Lee et al. 2019). They found that K510 and K514 are the predominant sites of automethylation in vivo.

\section{EZH2 methylation occurs in cis}

To better understand how the methylation loop may regulate EZH2 enzymatic activity, we asked whether automethylation occurred by a cis-acting mechanism (i.e., PRC2 methylating the EZH2 loop on the same protein complex) or a trans-acting mechanism (i.e., PRC2 methylating the EZH2 loop on a different protein complex).

To distinguish these possibilities, we developed a biochemical scheme that involved performing an HMTase assay on a 1:1 mixture of active PRC2 with an MBP tag on EZH2 ("MBP-EZH2") and untagged PRC2 with a catalytically dead EZH2 ("dEZH2"). The MBP tag on the active complex allows the unambiguous separation of active and inactive EZH2 proteins. To generate $\mathrm{dEZH} 2$, we introduced a $\mathrm{Y}>\mathrm{F}$ single-amino-acid mutation at position 726. The design was based on the crystal structure of the EZH2 SET domain (Wu et al. 2013), which shows the proximity of $\mathrm{Y} 726$ to the H3K27 substrate and the methyl donor cofactor (Fig. 4A); the mutation of the tyrosine prevents formation of an intermediate in the methyltransferase reaction. Following expression and purification, size exclusion chromatography of PRC2-dEZH2 showed a chromatogram identical to WT complexes, indicating that PRC2-dEZH2 was assembled and unaggregated. As shown by the HMTase assay in Figure 4B and Supplemental Figure 1A, our dEZH2 (Y726F) variant was indeed catalytically dead and did not methylate either H3 or its methylation loop. This result also eliminated the perhaps unlikely possibility that PRC2 methylation might be catalyzed by some trace contaminant enzyme that copurified with PRC2 instead of being catalyzed by PRC2 itself.

As shown in Figure 4C, considering a cis pathway, one would anticipate that mixing MBP-EZH2 and $\mathrm{dEZH} 2$ would produce only a single methylated band corresponding to MBP-EZH2. This is expected because MBP-EZH2 would be able to methylate only itself, and dEZH2 could not autocatalyze. Considering a trans pathway, one would expect to observe two methylated products because both MBP-EZH2 and dEZH2 have intact methylation loops that would be subjected to methylation by MBP-EZH2. In the key experiment (Fig. 4D, left gel, lane 3; Supplemental Fig. 1B), mixing of MBP-EZH2 and $\mathrm{dEZH} 2$ resulted in only one methylated band corresponding to MBP-EZH2, thereby confirming a cis-autocatalytic mechanism. The autoradiograph at the right in Figure 4D shows a similar mixing experiment using a catalytically compromised H694A variant reported previously (Kuzmichev et al. 2002), which still retained partial activity under our reaction conditions. The presence of the active PRC2 in the mixture failed to restore full methylation of this mutant PRC2, again supporting methylation in cis.

Mutation of the EZH2 methylation loop decreases H3K27 methylation in vitro and in cells

To assess the functional importance of PRC2 automethylation, we sought a mutant incapable of automethylation. We therefore mutated EZH2 $(\mathrm{K}>\mathrm{A})$ at sites 510, 514, and 515 (denoted here as methylmutant). Methylmutant 
A

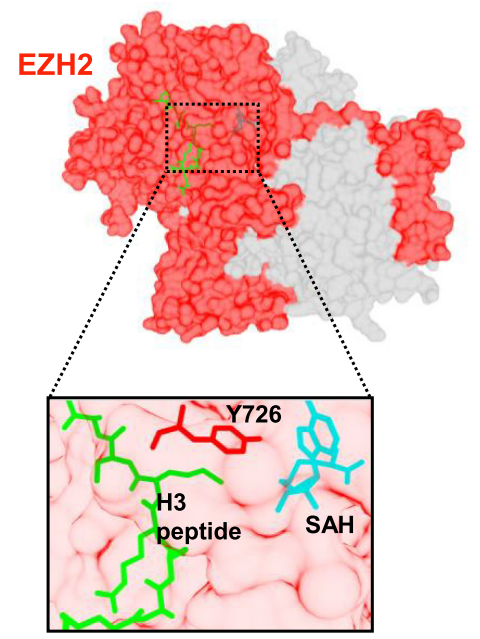

C

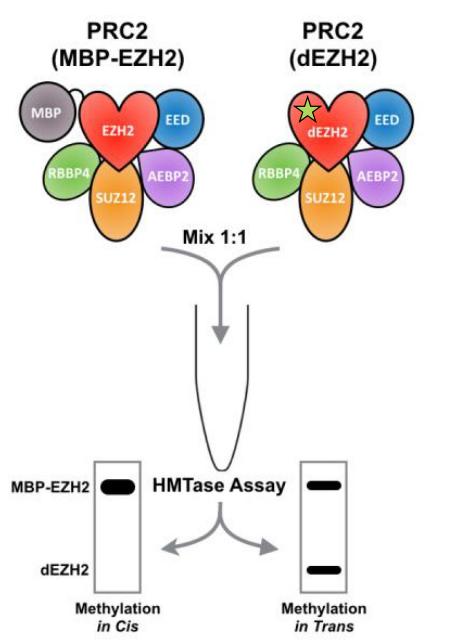

B

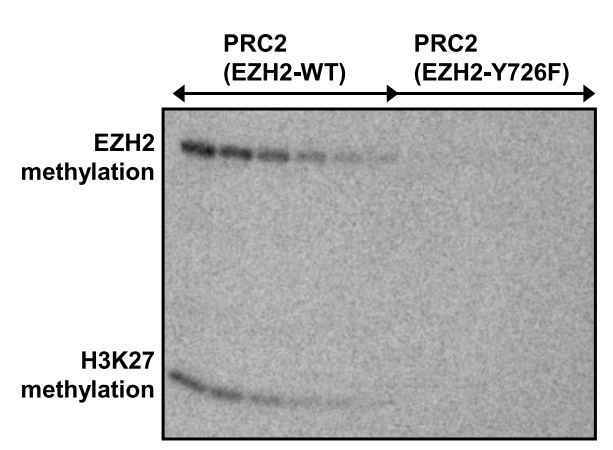

D

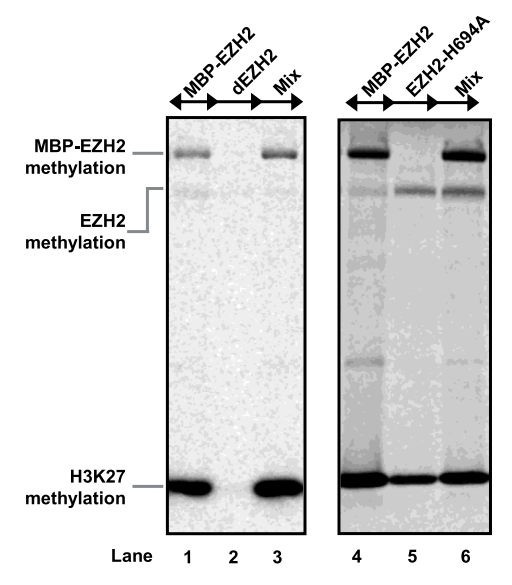

Figure 4. PRC2 automethylation occurs intramolecularly. (A) PRC2 core complex crystal structure ([red] EZH2; [gray] EED and SUZ12; PDB accession number: 5HYN) (Justin et al. 2016). The inset shows the proximity of SAH (cyan), H3 substrate (green), and the catalytic residue Y726 (red). PDB accession number: 5HYN. (B) Missense mutation (Y726F) resulted in a catalytically dead EZH2 (dEZH2) that abolished H3K27 methylation as well as EZH2 automethylation. Reactions were carried out between PRC2 and $\mathrm{H} 3$ in the presence of decreasing concentrations of ${ }^{14} \mathrm{C}-\mathrm{SAM}$ (twofold dilutions from $24 \mu \mathrm{M}$ to $750 \mathrm{nM}$ ). $(C)$ Design of mixing experiments to distinguish by cis- and trans-autocatalytic reactions. $(D)$ Mixing experiments between WT EZH2 and dEZH2 showing that automethylation occurs in cis. (Left) Experiments performed by mixing WT PRC2 1:1 with PRC2 catalytically dead mutant (Y726F). (Right) Experiments performed by mixing WT PRC2 1:1 with a catalytically impaired complex containing EZH2-H694A.
EZH2 was coexpressed with the other four PRC2 subunits in insect cells, and the resulting PRC2 complex formed a discrete peak in size exclusion chromatography (Supplemental Fig. 2) and had a subunit composition indistinguishable from WT PRC2 (Supplemental Fig. 3).

Normally, one compares the activity of a mutant enzyme to that of WT. However, we observed that different preparations of WT PRC2 showed different levels of automethylation during in vitro HMTase assays, ostensibly due to different levels of prior unlabeled automethylation during protein expression and purification. We therefore compared he HMTase activity of purified methylmutant PRC2 with that of WT PRC2 that had been preincubated with unlabeled SAM to drive automethylation as close to completion as possible.

HMTase assays were performed under multiple turnover conditions (excess H3 relative to PRC2, $12 \mu \mathrm{M} \mathrm{H} 3$ vs. $0.6 \mu \mathrm{M}$ PRC2). H3K27 methylation was reduced for the methylmutant relative to premethylated WT PRC2 on recombinant trinucleosomes (Fig. 5A) or native polynucleosomes extracted from HEK293 cells (Fig. 5B). Automethylation was largely eliminated for the methylmutant; the residual methylation occurred on the SUZ12 subunit (peptide TKASMSEFLESEDGEVEQQR). The methylmutant PRC2 bound trinucleosomes with an affinity similar to that of wild-type PRC2 (Supplemental Fig. 4), so the reduction in HMTase activity occurs at a step subsequent to formation of the enzyme-substrate complex. The observation that the methylmutant, which cannot automethylate, has reduced HMTase activity supports the conclusion that automethylation stimulates the HMTase activity of PRC2.

PRC2 methylation of nucleosomes is inhibited by RNA binding (Cifuentes-Rojas et al. 2014; Kaneko et al. 2014; Wang et al. 2017a,b). RNA-binding sites of EZH2 include amino acids 489-494 (Long et al. 2017a), which are in proximity to the automethylated lysines. However, we found that nucleosome methylation by methylmutant PRC2 was inhibited by RNA the same as WT PRC2 (Supplemental Fig. 5). Furthermore, RNA binding has little effect on automethylation (Wang et al. 2017b). Thus, automethylation and RNA binding appear to regulate PRC2 activity independently.

In contrast to the methylmutant (K510A K514A K515A), the double alanine mutant (K514A K515A) exhibited a very subtle reduction of H3K27 methylation activity compared with the WT PRC2, although automethylation of this double mutant was also largely reduced 
(Fig. 5A). This result indicates that K510 methylation could be most critical. We also made another mutant (mu$\operatorname{tant} \mathrm{K}>\mathrm{R}$ ) by mutating the three lysines to arginines, which preserves the positive charges. The triple $\mathrm{K}>\mathrm{R} \mathrm{mu}$ tant exhibited a reduction of automethylation but insignificant change in histone methylation compared with premethylated WT PRC2 on the trinucleosome substrate (Fig. 5B). Thus, at these positions in the methylation loop, it appears that arginines can to some extent mimic methylated lysines with respect to PRC2 activation.

To begin to understand the role of PRC2 automethylation in cells, we engineered a HEK293T cell line in which EZH2 expression was disrupted by introducing a frameshift with CRISPR genome editing. The persistence of a small amount of $\mathrm{H} 3 \mathrm{~K} 27 \mathrm{me} 3$ in this cell line (Fig. 5C, Western blot, lane "-") may represent methylation by EZH1-containing PRC2, as EZH1 has relatively lower expression (TPM [transcripts per kilobase million] of EZH2 is 47.4, while TPM of EZH1 is 13.3 [https://www .proteinatlas.org]). When WT or methylmutant EZH2 was overexpressed exogenously in this EZH2-depleted strain (Supplemental Fig. 6), immunofluorescence analysis indicated that both EZH2 variants correctly localized to the nucleus (Supplemental Fig. 7A). Western blot analysis indicated that the loss of $\mathrm{H} 3 \mathrm{~K} 27 \mathrm{me} 3$ in the EZH2-depleted strain was rescued by the WT EZH2 but not at all by the methylmutant EZH2, although both EZH2 variants were expressed at similar levels (Fig. 5C). Deposition of H3K27me2 was less affected by the methylmutant. This set of experiments suggests that EZH2 automethylation is essential for de novo trimethylation of H3K27.

We then made stable cell lines with WT or methylmutant EZH2 expressed at its endogenous locus (genotype verified in Supplemental Fig. 8; nuclear localization of EZH2 verified in Supplemental Fig. 7B); no significant difference in cell morphology or proliferation was observed (Supplemental Fig. 9). Importantly, H3K27me3 levels were similar between the WT and mutant (Fig. 5D; Supplemental Fig. 10). Compared with the rescue experiment described above, the CRISPR-edited stable cell lines had EZH2 continuously expressed through many population doublings. Because EZH1 is still lowly expressed in these cells, it is possible that EZH1-PRC2 compensates for the mutant EZH2-PRC2. Thus, an interesting possibility is that automethylation of PRC2 may be essential for de novo H3K27me3 deposition but that, over time, other factors may compensate to maintain H3K27me3 marks.

\section{Discussion}

A number of laboratories have observed automethylation of the core PRC2 complex (Müller et al. 2002; Whitcomb et al. 2012; Sanulli et al. 2015; Wang et al. 2017b), attributed to its EZH2 subunit, yet basic questions pertaining to this activity have gone unanswered. What is the site of this methylation? Of more significance, what is its physiological importance? By conducting biochemical and proteomic analyses of recombinant human PRC2 complexes, we identified a conserved methylation loop in EZH2 that is modified at three lysine residues (K510, K514, and K515) via a cis-acting mechanism. Our data support the notion that the EZH2 methylation loop serves an autoregulatory role and, when methylated, enhances EZH2 histone methylation activity. Furthermore, a triple-mutant EZH2 that cannot undergo automethylation is defective in rescuing H3K27 methylation in human cells in which the endogenous $E Z H 2$ gene has been disrupted.

How does the methylation loop modulate deposition of H3K27 methyl marks? Our biochemical data and sequence comparisons best support a model in which the flexible methylation loop acts as a pseudosubstrate for the EZH2 catalytic site (Fig. 6). The methylation loop occupies the lysine access channel in the SET domain of EZH2 via a trio of lysine residues and prevents or slows turnover. By an intramolecular reaction, PRC2 transfers methyl groups from SAM to itself at the three possible lysines. Methylation dislodges the loop, allowing for stimulated $\mathrm{H} 3$ tail binding and methylation. Given the lack of a charge difference between methylated and unmethylated lysine residues, loop displacement is driven not by charge neutralization but instead by steric effects. The Muir laboratory (Brown et al. 2014) determined that the EZH2 active site binds strongly to linear side chains and shows little tolerance for extra steric bulk or polar groups. Thus, methylation of the loop promotes its release from the EZH2 active site.

According to this pseudosubstrate model, the triple $\mathrm{K}$ > A mutant then has reduced HMTase activity because the mutated methylation loop is not efficiently displaced and blocks histone tail binding. On the other hand, the triple $\mathrm{K}>\mathrm{R}$ mutant has HMTase activity similar to that of premethylated WT PRC2, suggesting that the $\mathrm{K}>\mathrm{R}$ methylation loop is released from the active site. This may seem surprising, given that arginine often mimics lysine. However, the positive charge and bulky side chain of arginine also resemble methylated lysine. Thus, depending on the steric environment within the active site, it seems plausible that arginine substitution could mimic the automethylated state. Of course, arginine does not enable the switching on and off that is allowed by lysine automethylation.

Human EZH2 automethylation shows fundamental similarities to the recently discovered automethylation of the Clr4 H3K9 methyltransferase in Schizosaccharomyces pombe (Iglesias et al. 2018): In both cases, automethylation is intramolecular, occurs on a disordered loop, and increases histone methyltransferase activity. The human homolog SUV39H2 undergoes automethylation at a corresponding lysine (Piao et al. 2016; Iglesias et al. 2018). Thus, it now appears that the formation of multiple types of heterochromatin-containing $\mathrm{H} 3 \mathrm{~K} 9 \mathrm{me} 3$ and/or H3K27me3 marks-may be similarly regulated by automethylation of the respective histone methyltransferases.

How does the methylation loop sequence compare with known PRC2 methylation targets? Intriguingly, comparison of the EZH2 methylation sites identified here with sequences predicted to serve as efficient substrates for PRC2 (Kuzmichev et al. 2002; Ardehali et al. 2017) revealed notable insights. The Kingston laboratory (Ardehali et al. 
Wang et al.

A Recombinant trinucleosome

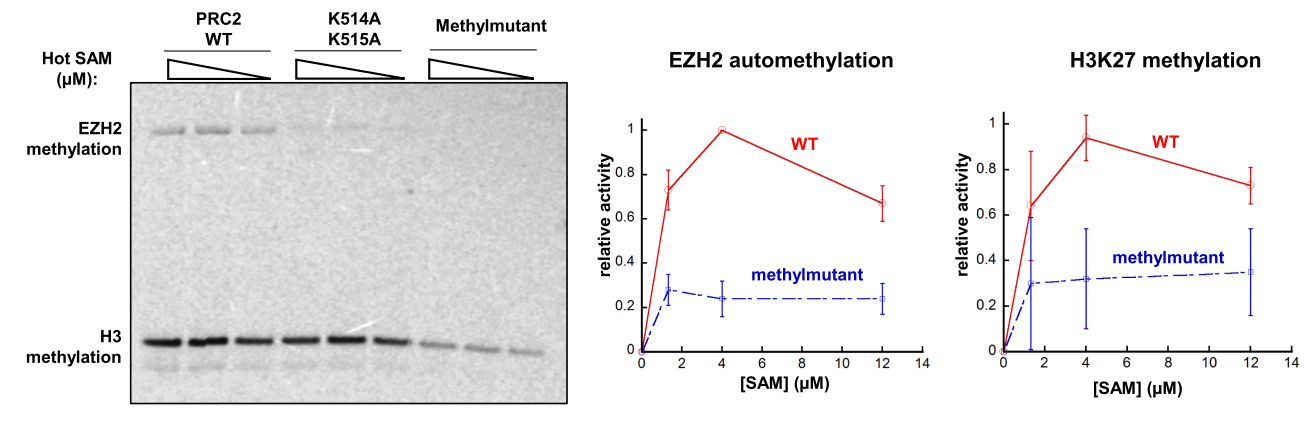

B Native polynucleosome
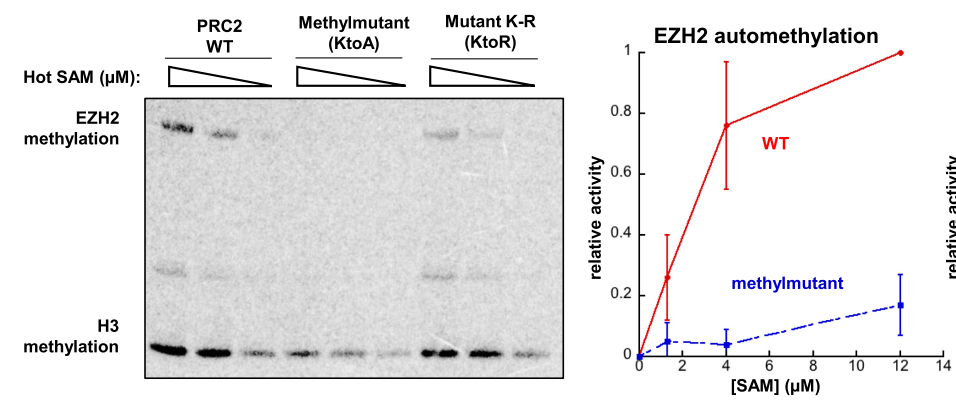

H3K27 methylation
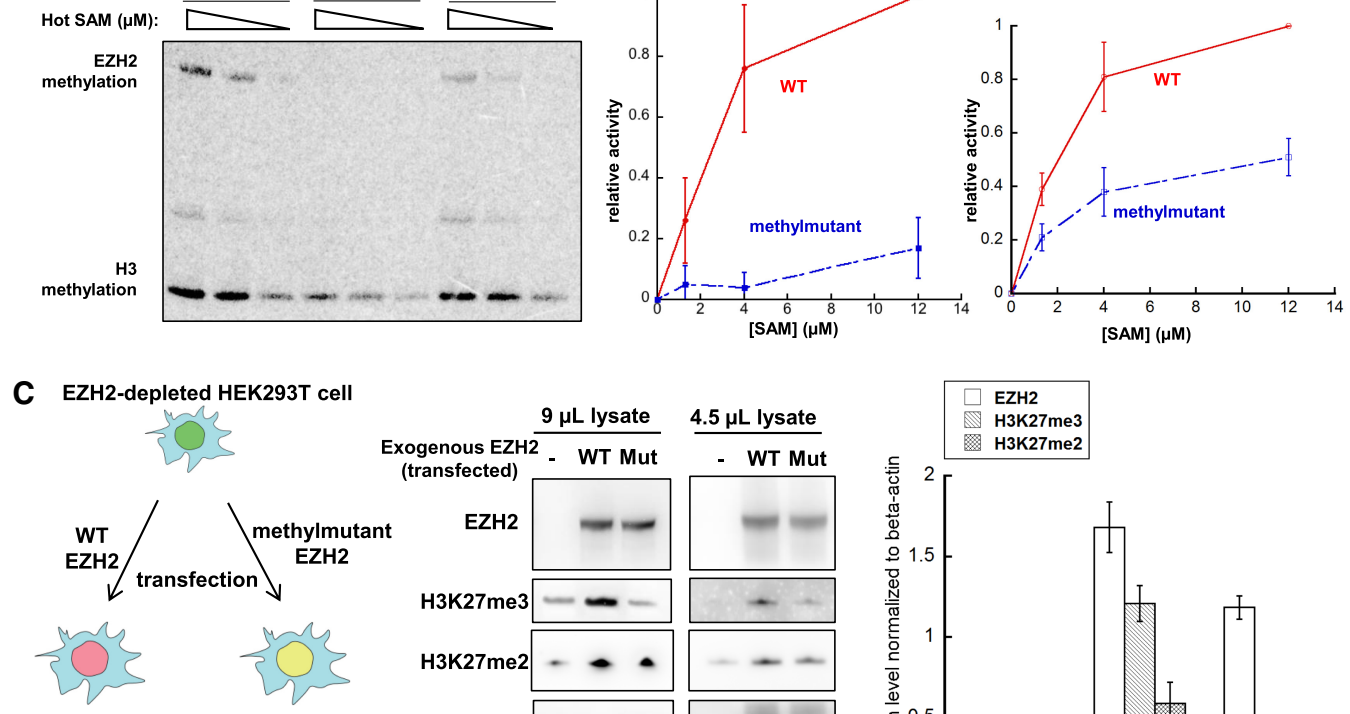

What is the H3K27me3 level?
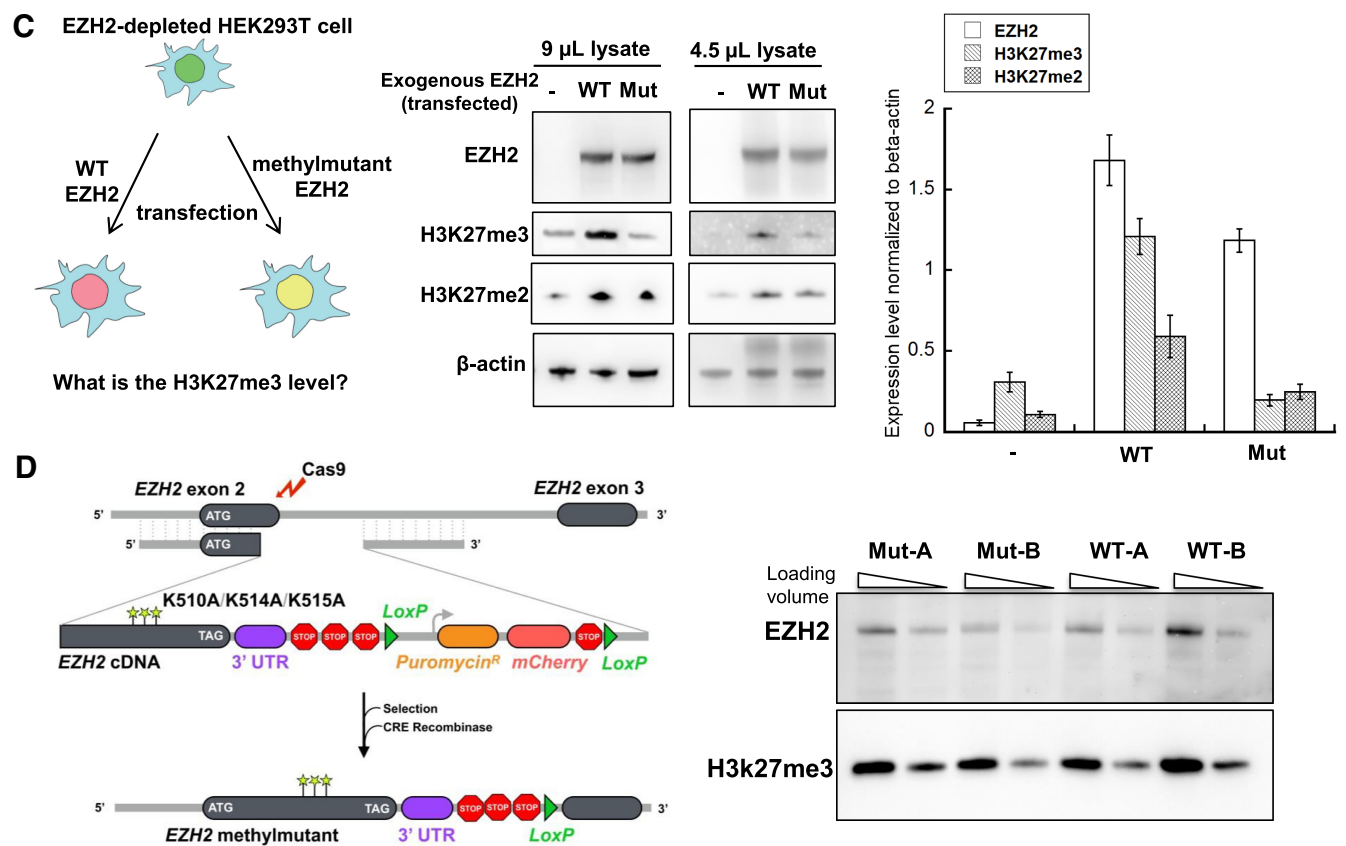

Figure 5. Mutation of the automethylated lysines decreases PRC2 HMTase activity in vitro and in vivo. $(A)$ Mutation of the three lysines (K510A K514A K515A, "methylmutant") decreases PRC2 activity on reconstituted trinucleosomes relative to activity of WT PRC2 preincubated with SAM. Another mutant (K514A K515A) showed less perturbation of catalytic activity. Radioactive ${ }^{14} \mathrm{C}$-SAM was titrated from 1.3 to $12 \mu \mathrm{M}$. (Right) Quantification of the automethylation and H3K27 methylation signal of WT and methylmutant $(\mathrm{mean} \pm \mathrm{SD}, n=$ 3). (B) Mutation of the three lysines (K > A) decreases PRC2 activity on native polynucleosome substrate, whereas the triple $\mathrm{K}>\mathrm{R}$ mutant has substantially normal activity. (C) EZH2 automethylation is essential for de novo H3K27me3 deposition. (Left) WT or methylmutant EZH2 plasmid was transfected into the EZH2-depleted HEK293T strain to test for restoration of the H3K27me3 level. (Middle) Western blot results of the strains transfected with WT, methylmutant, or blank control, with $\beta$-actin used as a loading control. Nine microliters or $4.5 \mu \mathrm{L}$ of lysate was loaded on the gel for Western blot analysis. (Right) Quantification of the EZH2, H3K27me3, and H3K27me2 Western blot results $(9 \mu \mathrm{L}$ of lysate), normalized to $\beta$-actin. (D) EZH2 automethylation is dispensable for H3K27me3 maintenance. (Left) CRISPRCas9 gene-editing scheme. cDNA encoding the remaining amino acids of full-length EZH2 is inserted into exon 2 of the EZH2 locus. The cDNA to make the methylmutant encodes $\mathrm{K}>\mathrm{A}$ mutations in the methylation loop at sites 510, 514, and 515. (Right) Western blot analysis of EZH2 WT and methylmutant cell lines shows that H3K27me3 levels are similar between the two lines. 


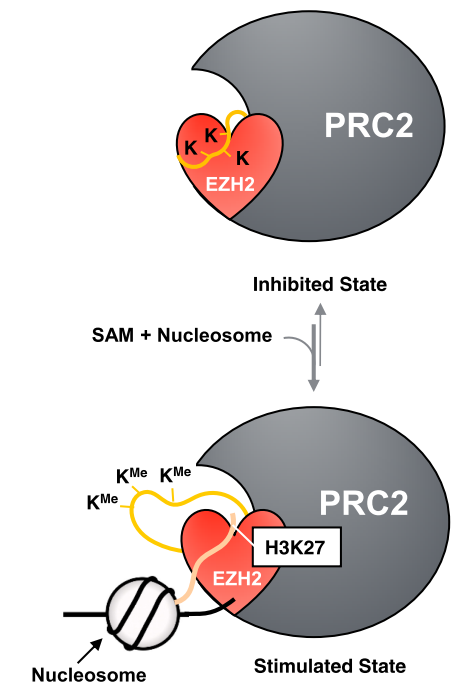

Figure 6. Model for autoregulation of PRC2 by automethylation of three lysine residues in EZH2. In the absence of EZH2 automethylation, the flexible loop containing the three key lysines is bound to the active site of EZH2, preventing H3 substrate from entering. This is the inhibited state. In the presence of cofactor SAM, the three lysine residues can be methylated and then released from the catalytic active site. This results in a stimulated state, in which binding of $\mathrm{H} 3$ tail and $\mathrm{H} 3 \mathrm{~K} 27$ methylation are active.

2017) determined recently that substrate regions critical for productive interaction with the PRC2 catalytic pocket typically contain an $(\mathrm{R} / \mathrm{K}) \mathrm{K}$ amino acid motif. Neighboring the targeted lysine at position -1 , the arginine $(\mathrm{R})$ or lysine $(\mathrm{K})$ is thought to be critical due to hydrogen bonding that stabilizes peptide binding. Positions -1 of K510 and K515 in the EZH2 methylation loop are occupied by arginine (R509) and lysine (K514), respectively. Another protein target of PRC2 activity is JARID2 (Sanulli et al. 2015; Wang et al. 2017b), which is methylated at K116 and has a position -1 arginine (R115). Last, the natural H3 sequence also has a stabilizing arginine (R26) neighboring K27 (Kuzmichev et al. 2002).

Why might activation via automethylation be useful to PRC2? EZH2 automethylation appears to activate PRC2 in response to SAM concentration, in the sense that increased SAM gives more automethylation, which then makes PRC2 more active. Therefore, automethylation may serve as a sensor for cellular SAM concentration and level of pre-existing H3K27me3 marks. This regulatory role could be important during transition of cell types (e.g., stem cell conversion and differentiation) where de novo H3K27 methylation is required. Our CRISPR-editing experiment did not see such a large effect of automethylation in maintenance of pre-existing H3K27 methylation (Fig. 5C,D), which could imply that steady-state level of pre-existing H3K27me3 marks may overcome the activity drop due to the loss of automethylation.

There also remains an outstanding question of whether cellular methyltransferases and demethylases might be able to regulate PRC2 automethylation levels in order to modulate PRC2 function. Quite interestingly, we observed that a viral SET domain methyltransferase specific to $\mathrm{H} 3 \mathrm{~K} 27$ is capable of methylating PRC2 in vitro (data not shown). In addition to PRC2, another histone methyltransferase, G9a, has been demonstrated to automethylate. This automethylation provides wider substrate specificity and modulates binding of additional proteins (Chin et al. 2007; Sampath et al. 2007). We are completely open to the possibility that automethylation of EZH2 could regulate its association with other proteins. In other examples of methylation of nonhistone proteins, these marks act as important regulators of cellular signal transduction in MAPK and NF-kB signaling pathways (Levy et al. 2011; Mazur et al. 2014). In these cases, cross-talk between histone and non-histone protein methylation also occurs and affects cellular processes such as chromatin remodeling, gene transcription, and protein synthesis.

What might be the therapeutic significance of understanding new PRC2 regulatory features? PRC2, one of the few enzymes in cells associated with gene silencing, is a natural candidate for epigenetic therapy. Indeed, cancers harboring mutations in the EZH2 subunit of PRC2 have been shown to be susceptible to small molecule inhibitors that are currently in clinical development. For example, missense mutations in EZH2 are reported in follicular lymphoma and diffuse large B-cell lymphoma. The most prevalent mutation occurs at Y646 of EZH2, which is frequently altered to $\mathrm{C}, \mathrm{F}, \mathrm{H}, \mathrm{N}$, or S. These activating mutations cause H3K27 hypermethylation in vitro and in vivo and have been suggested to be associated with malignant transformation (Yap et al. 2011; Berg et al. 2014). Early studies using highly selective EZH2 inhibitors to treat follicular lymphoma and diffuse large B-cell lymphoma bearing these mutations have demonstrated some treatment success (McCabe et al. 2012). Based on our automethylation analysis, such EZH2 inhibitors should not only inhibit histone $\mathrm{H} 3$ methylation directly but also inhibit PRC2 activation through automethylation.

Intriguingly, the cancer genomic databases (Cerami et al. 2012; Gao et al. 2013) also report mutations in K510 and K515 of EZH2 (Supplemental Fig. 11), residues that we described here to be key targets of automethylation and PRC2 autoregulation. The implication is that PRC2 might possibly be dysregulated at the level of the methylation loop in some cancers. Future in vivo studies are needed to test this hypothesis. Certainly, the data shown here provide new insights into the regulatory complexity of PRC2 and suggest that PRC2 evolved the ability to exquisitely fine-tune its activity in multiple ways. Our findings contribute to foundational knowledge for future studies pursuing an understanding of how PRC2 regulation can go awry in diseases.

\section{Materials and methods}

Protein expression and purification

Human PRC2-5m complexes, comprising EZH2, EED, SUZ12, RBBP4, and AEBP2 (UniProtDB entry isoform sequences 
Q15910-2, Q15022, O75530-1, Q09028-1, and Q6ZN18-1, respectively), were expressed in insect cells. In brief, standard Bac-toBac baculovirus expression system (Expression System) was used to generate baculovirus stocks based on standard protocol. Gp64 detection was used for titering each baculovirus stock (Expression Systems). Sf9 cells (Invitrogen) were grown to a density of $2.0 \times 10^{6}$ cells per milliliter, followed by infection with equal amounts of baculovirus for each subunit. The cells were incubated at $130 \mathrm{rpm}$ for an additional $72 \mathrm{~h}$ at $27^{\circ} \mathrm{C}$, harvested, and snapfrozen with liquid nitrogen for later purification.

A three-column purification scheme was used to purify PRC2 5-mer complexes as described previously (Wang et al. 2017a). Briefly, insect cells were lysed in lysis buffer $(10 \mathrm{mM}$ Tris-HCl at $\mathrm{pH} 7.5$ at $25^{\circ} \mathrm{C}, 150 \mathrm{mM} \mathrm{NaCl}, 0.5 \%$ Nonidet P-40, $1 \mathrm{mM}$ TCEP), and cell lysate was bound to the amylose resin and washed thoroughly. The protein was eluted with $10 \mathrm{mM}$ maltose followed by concentrating to $\sim 15 \mathrm{mg} / \mathrm{mL}$ as final concentrations. PreScission protease was used to digest eluted protein at a mass ratio of 1:50 protease:protein. After overnight incubation at $4^{\circ} \mathrm{C}$, cleavage efficiency was checked by SDS-PAGE. The cleaved protein was subjected to a $5-\mathrm{mL}$ Hi-Trap heparin column /GE, 170407-03) with a gradient over 35 column volumes from buffer A $(10 \mathrm{mM}$ Tris at $\mathrm{pH} 7.5$ at room temperature, $150 \mathrm{mM} \mathrm{NaCl}$, $1 \mathrm{mM}$ TCEP) to buffer B (10 mM Tris at $\mathrm{pH} 7.5$ at room temperature, $2 \mathrm{M} \mathrm{NaCl}, 1 \mathrm{mM}$ TCEP), with a flow rate of $1.5 \mathrm{~mL} / \mathrm{min}$. All of the peak fractions were checked by SDS-PAGE, and the PRC2 fractions were pooled and concentrated. The concentrated protein was subjected to the final sizing column: Superose 6 Increase $10 / 300 \mathrm{GL}$ with running buffer $(25 \mathrm{mM} \mathrm{NaCl}, 10 \mathrm{mM}$ Tris- $\mathrm{HCl}$ at $\mathrm{pH} 7.5$ at room temperature, $1 \mathrm{mM}$ TCEP at $\mathrm{pH}$ 7) with a flow rate of $0.5 \mathrm{~mL} / \mathrm{min}$. PRC2-peak fractions were checked with SDS-PAGE. The correct fractions were pooled and concentrated as above. Final protein concentration was calculated by nanodrop (UV absorbance at $280 \mathrm{~nm}$ ). The ratio of absorbance at $260 \mathrm{~nm} / 280 \mathrm{~nm}<0.7$ was observed, suggesting no nucleic acid contamination.

\section{In vitro histone methyltransferase assay}

In each 10- $\mu \mathrm{L}$ reaction, recombinant PRC2-5m, H3 (New England Biolabs, M2503S), and $S$-[methyl- $\left.{ }^{14} \mathrm{C}\right]$-adenosylmethionine (PerkinElmer, NEC363050UC) were mixed in methylation buffer $\left(50 \mathrm{mM}\right.$ Tris- $\mathrm{HCl}$ at $\mathrm{pH} 8.0$ at $30^{\circ} \mathrm{C}, 100 \mathrm{mM} \mathrm{KCl}, 2.5 \mathrm{mM} \mathrm{MgCl}_{2}$, $0.1 \mathrm{mM} \mathrm{ZnCl}, 2 \mathrm{mM} 2$-mercaptoethanol, $0.1 \mathrm{mg} / \mathrm{mL}$ bovine serum albumin, $5 \%$ [v/v] glycerol). All of the methylation reactions were incubated for $1 \mathrm{~h}$ at $30^{\circ} \mathrm{C}$ followed by addition of $4 \times$ loading dye to stop each reaction and heated for $5 \mathrm{~min}$ at $95^{\circ} \mathrm{C}$. Each reaction was then loaded onto a $4 \%-12 \%$ Bis-Tris gel (Thermo Fisher, NP0322BOX). Gel electrophoresis was carried out for $48 \mathrm{~min}$ at room temperature at $180 \mathrm{~V}$. Gels were stained by InstantBlue for $1 \mathrm{~h}$ and destained with water overnight. Three sheets of Whatman 3-mm chromatography paper were put underneath the gel, and gels were scanned followed by vacuum drying for $60 \mathrm{~min}$ at $80^{\circ} \mathrm{C}$. Dried gels were subjected to phosphorimaging plates, and radioactive signal was acquired with a Typhoon Trio PhosphorImager (GE Healthcare). Densitometry and analysis were carried out with ImageQuant software (GE Healthcare). For activity assays on nucleosomes in Figure 5, recombinant trinuclesomes were reconstituted as described previously (Wang et al. 2017b), and native nucleosomes of HEK293 cells were purchased from Asmbio (52015); methylation buffer contained $10 \mathrm{mM} \mathrm{KCl}$ instead of $100 \mathrm{mM} \mathrm{KCl}$, and reaction time was $4 \mathrm{~h}$. For the experiments of preincubating WT PRC2 with unlabeled SAM, PRC2 was incubated with $0.3 \mathrm{mM}$ SAM at the precision cleavage step of the purification process overnight at $4^{\circ} \mathrm{C}$.

\section{Site-directed mutagenesis}

Mutant EZH2 genes were generated using the QuickChange II site-directed mutagenesis kit (Stratagene). The appropriate mutations were confirmed by DNA sequencing.

\section{Mass spectrometry detection and analysis}

Methylation experiments were set up as above. Mass spectrometry experiment and analysis were performed at the Core Facility of University of Colorado at Boulder. Samples were processed using standard protocol. In brief, protein samples (32 $\mu \mathrm{g}$ of PRC2-5m complex) were diluted with an incubation buffer (50 mM Tris at $\mathrm{pH} 7.6,5 \mathrm{mM} \mathrm{CaCl}_{2}, 2 \mathrm{mM}$ EDTA). TCEP ( $5 \mathrm{mM}$ ) was used to reduce the reaction for $30 \mathrm{~min}$ at $60^{\circ} \mathrm{C}$ followed by alkylating with $15 \mathrm{mM}$ iodoacetamide for $20 \mathrm{~min}$ at room temperature. DTT (7.5 mM) was added to quench unreacted iodoacetamide. The reactions were digested with $0.6 \mu \mathrm{g}$ of sequencing-grade Arg-C (Promega) overnight at $37^{\circ} \mathrm{C}$, then desalted with Pierce C18 columns (Thermo Scientific), and dried with vacuum centrifugation. Prior to LC-MS/MS analysis, buffer A (0.1\% formic acid in water) was used to reconstitute the peptides.

For LC-MS/MS analysis, a Waters nanoACQUITY UPLC BEH C18 column (130 ̊, $1.7 \mu \mathrm{m} \times 75 \mu \mathrm{m} \times 250 \mathrm{~mm}$ ) was first equilibrated with $0.1 \%$ formic acid/3\% acetonitrile/water followed by peptide loading. Each load was an aliquot $(5 \mu \mathrm{L}, 1 \mu \mathrm{g})$ of the peptides. Next, $0.1 \%$ formic acid/water was used as the mobile phase $\mathrm{A}$, and $0.1 \%$ formic acid/acetonitrile was used as phase B. The elution was done at the rate of $0.3 \mu \mathrm{L} / \mathrm{min}$ using gradients of $3 \%-8 \% \mathrm{~B}(0-5 \mathrm{~min})$ and $8 \%-32 \% \mathrm{~B}(5-123 \mathrm{~min})$. A LTQ Orbitrap Velos mass spectrometer was used for MS/MS. The precursor ions were scanned between 300 and $1800 \mathrm{~m} / \mathrm{z}\left(1 \times 10^{6}\right.$ ions, 60,000 resolution). The 10 most intense ions were selected with 180 -sec dynamic exclusion, $10 \mathrm{ppm}$ exclusion width, repeat $\operatorname{count}=1$, and 30 -sec repeat duration. Ions were excluded based on unassigned charge state and $\mathrm{MH}+1$ from the MS/MS. Maximal ion injection times were set as $500 \mathrm{msec}$ for FT (one microscan) and 250 msec for LTQ. The automatic gain control was $1 \times 10^{4}$, and the normalized collision energy was set as $35 \%$ with activation $Q$ 0.25 for $10 \mathrm{msec}$.

For database search, MaxQuant/Andromeda (version 1.5.2.8) was used. The raw files from LTQ-orbitrap were processed. The peak was searched against UniProt human proteome. In the search, Arg-C specificity with a maximum of two missed cleavages was used. Several modifications, including carbamidomethyl modification on cysteine as a fixed modification and protein $\mathrm{N}$-terminal acetylation, oxidation on methionine, and methylation on lysine or arginine as variable modifications, were set. In addition, search tolerance was set as $4.5 \mathrm{ppm}$ main search tolerance for precursor ions, and match tolerance was placed as 0.5-Da MS/MS match tolerance, searching the top eight peaks per $100 \mathrm{Da}$. Finally, false discovery rate was put as 0.01 with a minimum seven-amino-acid peptide length.

\section{CRISPR editing to inactivate EZH2 genes in HEK293T cells}

A CRISPR plasmid encoding Cas 9 and the guide RNA was made by inserting the sgRNA sequence (CAGACGAGCTGATGAAGTAA) targeting exon 2 (toward the junction with intron 2) of the EZH2 gene in pX330 (Addgene, 42230).CRISPR plasmid (1.2 $\mu \mathrm{g}$ ) and an equal amount of donor plasmid were transfected to 1 million HEK293T cells in a six-well plate using Lipofectamine 2000 according to the manufacturer's instructions. Cells were passaged to a $15-\mathrm{cm}$ plate after $1 \mathrm{~d}$, and $1 \mu \mathrm{g} / \mathrm{mL}$ puromycin was added to the culture $2 \mathrm{~d}$ later. Cells were selected in the presence of puromycin for $1 \mathrm{wk}$, and the surviving cells were sorted into 96 wells 
(one cell per well) in order to obtain single clones. Genomic DNA samples were extracted, and PCR was used to analyze the area flanking the Cas9 cleavage site (two primers: GCTGCAGCAT CATCTAACCTGG and CAGTGAGTCAGAAAACCTTGCTC). The amplicon was gel-extracted and then sequenced to validate the frameshift caused by indels.

\section{Transfection of EZH2 and Western blotting}

EZH2-depleted HEK293T cells grown in DMEM were transfected with $2.5 \mu \mathrm{g}$ of the WT and mutant EZH2 (with N-terminal 3xFlag tag) plasmids in six-well plates using Lipofectamine 2000 reagent (Life Technologies). At $48 \mathrm{~h}$ after transfection, media were aspirated, and cells were harvested by adding $200 \mu \mathrm{L}$ of $1 \times$ NuPAGE LDS sample buffer (Invitrogen NP0007) and $2 \mu \mathrm{L}$ of benzonase nuclease (Sigma, E1014) per well. Lysate was incubated for $30 \mathrm{~min}$ at $37^{\circ} \mathrm{C}$ to completely digest nucleic acids. Ten microliters of each lysate was resolved in a NuPAGE $4 \%-12 \%$ bis-tris protein gel (Thermo Fisher) and then transferred to a Hybond ECL membrane (GE, RPN78D) in $1 \times$ transfer buffer (25 mM Tris base, $192 \mathrm{mM}$ glycine, $0.1 \%$ SDS, $20 \%$ methanol) at 0.5 amps constant for $1 \mathrm{~h}$. The membrane was blocked with $10 \mathrm{~mL}$ of StartingBlock T20 (PBS) blocking buffer (Thermo, 37539) for $30 \mathrm{~min}$ at room temperature, incubated with each of the three antibodies (EZH2 [Cell Signaling, 5246S], 1:1000; H3K27me2 [Cell Signaling, 9728S], 1:500; H3K27me3 [Cell Signaling, 9733S], 1:500; and $\beta$-actin: [MA1-91399], 1:10,000) in $10 \mathrm{~mL}$ of blocking buffer for $1 \mathrm{~h}$, washed three times with $10 \mathrm{~mL}$ of $1 \times$ PBS with $0.05 \%$ Tween 20 , incubated with the corresponding secondary antibodies (Jackson ImmunoResearch, antirabbit [711-035-152] and antimouse [715035-150]), washed three times with $10 \mathrm{~mL}$ of $1 \times$ PBS with $0.05 \%$ Tween 20 and once with $10 \mathrm{~mL}$ of $1 \times$ PBS, and developed using SuperSignal West Pico chemiluminescent substrate kit (Thermo Scientific, 34080).

\section{CRISPR editing of WT and methylmutant EZH2 in HEK293T cells}

Two plasmids were made for the CRISPR editing. A CRISPR plasmid encoding Cas9 and the guide RNA was made by inserting the sgRNA sequence (CAGACGAGCTGATGAAGTAA) targeting exon 2 of the EZH2 gene into pX330 as described previously (Cong et al. 2013) .Two donor plasmids carrying either the WT or mutant EZH2 cDNA were made by assembling the following fragments into a previously described donor plasmid (Schmidt et al. 2016): left homology arm (-951 to -14 , relative to the ATG start codon), EZH2 cDNA, EZH2 3' UTR (872 bp immediately after the stop codon), $3 \times$ SV40 polyadenylation sites, $1 \times$ bGH polyadenylation site, SV40 promoter, puromycin resistance ORF, T2A self-cleavage site, mCherry ORF, SV40 polyadenylation site, and right homology arm $1+25$ to +830 , relative to ATG). CRISPR plasmid $(1.2 \mu \mathrm{g})$ and an equal amount of donor plasmid were transfected to 1 million HEK293T cells in a sixwell plate using Lipofectamine 2000 according to the manufacturer's instructions. Cells were passaged to a $15-\mathrm{cm}$ plate after $1 \mathrm{~d}$, and $1 \mu \mathrm{g} / \mathrm{mL}$ puromycin was added to the culture $2 \mathrm{~d}$ later. Cells were selected in the presence of puromycin for $1 \mathrm{wk}$, and the surviving cells were pooled into a well of a six-well plate. A Cre-GFP plasmid was transfected, and cells with both GFP and mCherry signal were selected and sorted into 96-well plates using flow cytometry after $24 \mathrm{~h}$. When each clone reached confluency, cells were passaged, and a fraction was used for genomic DNA extraction as described previously (Laird et al. 1991). Four primers were used for verification of the correct genome editing: P1 (GC TGCAGCATCATCTAACCTGG), P2 (CAGTGAGTCAGAAAA CCTTGCTC), P3 (ATCATCTCGGTGATCCTCCAG), and P4
(TGAGCAGTCCTGAAAGCAGTTATT.) PCR products were analyzed on a $1 \%$ agarose TAE gel. Western blot analysis and antibody usage were the same as described above.

\section{Immunofluorescence}

Cells grown on eight-well slides were fixed with $4 \%$ formaldehyde in PBS for 10 min and then permeabilized in extraction buffer $(0.5 \%$ Triton X-100, $20 \mathrm{mM}$ HEPES-KOH at $\mathrm{pH} 7.9,50 \mathrm{mM}$ $\mathrm{NaCl}, 3 \mathrm{mM} \mathrm{MgCl} 2,300 \mathrm{mM}$ sucrose) for $10 \mathrm{~min}$. Slides were then washed with PBS $+0.1 \%$ Triton X-100 twice and blocked in ABDIL buffer ( $3 \%$ BSA, $0.1 \%$ Triton X-100 in PBS). Primary antibody (EZH2 antibody [Cell Signaling Technology, 5246] or Flag antibody [Sigma, F3165], both 1:200 dilution) diluted in ABDIL buffer was then added for a 1-h incubation, and secondary antibody (antirabbit Alexa 488 [Life Technologies] and anti-mouse Alexa 647 [Life Technologies]; 1:500 dilution) was added after washing three times with PBS. After washing another three times with PBS, cells were mounted using ProLong Diamond antifade mountant (Life Technologies, P36970). All images were acquired on a DeltaVision Core microscope (Applied Precision) and a sCMOS camera.

\section{Competing interest statement}

T.R.C. is on the board of directors of Merck, Inc., and is a scientific advisor of Storm Therapeutics, Inc.

\section{Acknowledgments}

We thank members of the Cech laboratory for useful discussion. We are grateful to Jeremy Balsbaugh (University of Connecticut) for performing the initial mass spectrometry experiments, and Chen Davidovich (Monash University, Australia) for the initial discussion of this project. Uploading the initial version of this manuscript to bioRxiv stimulated productive discussions with Danny Reinberg and his laboratory (New York University), and we thank them for their thoughtful input and sharing of materials. T.R.C. is an investigator of the Howard Hughes Medical Institute.

Author contributions: X.W. and R.D.P. performed the initial in vitro analysis with input from T.R.C. Upon the graduation of X.W. and R.D.P., Y.L. assumed leadership of the project with assistance from A.R.G. and R.M.B. Y.L. designed and performed the in vivo experiments. T.L. was responsible for mass spectrometry. X.W., Y.L., and T.R.C. wrote the manuscript with input from all authors.

\section{References}

Ardehali MB, Anselmo A, Cochrane JC, Kundu S, Sadreyev RI, Kingston RE. 2017. Polycomb repressive complex 2 methylates Elongin A to regulate transcription. Mol Cell 68: 872884.e6. doi:10.1016/j.molcel.2017.10.025

Beltran M, Yates CM, Skalska L, Dawson M, Reis FP, Viiri K, Fisher CL, Sibley CR, Foster BM, Bartke T, et al. 2016. The interaction of PRC2 with RNA or chromatin is mutually antagonistic. Genome Res 26: 896-907. doi:10.1101/gr.197632.115

Berg T, Thoene S, Yap D, Wee T, Schoeler N, Rosten P, Lim E, Bilenky M, Mungall AJ, Oellerich T, et al. 2014. A transgenic mouse model demonstrating the oncogenic role of mutations in the polycomb-group gene EZH2 in lymphomagenesis. Blood 123: 3914-3924. doi:10.1182/blood-2012-12-473439 
Brown ZZ, Müller MM, Jain SU, Allis CD, Lewis PW, Muir TW. 2014. Strategy for "detoxification" of a cancer-derived histone mutant based on mapping its interaction with the methyltransferase PRC2. J Am Chem Soc 136: 13498-13501. doi:10 $.1021 /$ ja5060934

Cerami E, Gao J, Dogrusoz U, Gross BE, Sumer SO, Aksoy BA, Jacobsen A, Byrne CJ, Heuer ML, Larsson E, et al. 2012. The cBio cancer genomics portal: an open platform for exploring multidimensional cancer genomics data. Cancer Discov 2: 401-404. doi:10.1158/2159-8290.CD-12-0095

Chin HG, Estève P-O, Pradhan M, Benner J, Patnaik D, Carey MF, Pradhan S. 2007. Automethylation of G9a and its implication in wider substrate specificity and HP1 binding. Nucleic Acids Res 35: 7313-7323. doi:10.1093/nar/gkm726

Cifuentes-Rojas C, Hernandez AJ, Sarma K, Lee JT. 2014. Regulatory interactions between RNA and polycomb repressive complex 2. Mol Cell 55: 171-185. doi:10.1016/j.molcel.2014 .05 .009

Cliffe AR, Garber DA, Knipe DM. 2009. Transcription of the herpes simplex virus latency-associated transcript promotes the formation of facultative heterochromatin on lytic promoters. J Virol 83: 8182-8190. doi:10.1128/JVI.00712-09

Cong L, Ran FA, Cox D, Lin S, Barretto R, Habib N, Hsu PD, Wu X, Jiang W, Marraffini LA, et al. 2013. Multiplex genome engineering using CRISPR/Cas systems. Science 339: 819-823. doi:10.1126/science.1231143

Davidovich C, Cech TR. 2015. The recruitment of chromatin modifiers by long noncoding RNAs: lessons from PRC2. RNA 21: 2007-2022. doi:10.1261/rna.053918.115

Davidovich C, Zheng L, Goodrich KJ, Cech TR. 2013. Promiscuous RNA binding by Polycomb repressive complex 2. Nat Struct Mol Biol 20: 1250-1257. doi:10.1038/nsmb.2679

Gao J, Aksoy BA, Dogrusoz U, Dresdner G, Gross B, Sumer SO, Sun Y, Jacobsen A, Sinha R, Larsson E, et al. 2013. Integrative analysis of complex cancer genomics and clinical profiles using the cBioPortal. Sci Signal 6: pll.

Hurley JH, Dean AM, Sohl JL, Koshland DE, Stroud RM. 1990. Regulation of an enzyme by phosphorylation at the active site. Science 249: 1012-1016. doi:10.1126/science.2204109

Iglesias N, Currie MA, Jih G, Paulo JA, Siuti N, Kalocsay M, Gygi SP, Moazed D. 2018. Automethylation-induced conformational switch in Clr4 (Suv39h) maintains epigenetic stability. Nature 560: 504-508. doi:10.1038/s41586-018-0398-2

Justin N, Zhang Y, Tarricone C, Martin SR, Chen S, Underwood E, De Marco V, Haire LF, Walker PA, Reinberg D, et al. 2016. Structural basis of oncogenic histone H3K27M inhibition of human polycomb repressive complex 2. Nat Commun 7: 11316. doi:10.1038/ncomms11316

Kaneko S, Son J, Bonasio R, Shen SS, Reinberg D. 2014. Nascent RNA interaction keeps PRC2 activity poised and in check. Genes Dev 28: 1983-1988. doi:10.1101/gad.247940.114

Kasinath V, Faini M, Poepsel S, Reif D, Feng XA, Stjepanovic G, Aebersold R, Nogales E. 2018. Structures of human PRC2 with its cofactors AEBP2 and JARID2. Science 359: 940-944. doi:10.1126/science.aar5700

Krebs EG, Graves DJ, Fischer EH. 1959. Factors affecting the activity of muscle phosphorylase b kinase. I Biol Chem 234: 2867-2873.

Kuzmichev A, Nishioka K, Erdjument-Bromage H, Tempst P, Reinberg D. 2002. Histone methyltransferase activity associated with a human multiprotein complex containing the enhancer of Zeste protein. Genes Dev 16: 2893-2905. doi:10 $.1101 /$ gad.1035902
Laird PW, Zijderveld A, Linders K, Rudnicki MA, Jaenisch R, Berns A. 1991. Simplified mammalian DNA isolation procedure. Nucleic Acids Res 19: 4293. doi:10.1093/nar/19.15.4293

Lee C-H, Yu J-R, Granat J, Saldaña-Meyer R, Andrade J, LeRoy G, Jin Y, Lund P, Stafford JM, Garcia BA, et al. 2019. Automethylation of PRC2 promotes H3K27 methylation and is impaired in H3K27M pediatric glioma. Genes Dev (this issue). doi:10 $.1101 /$ gad.328773.119

Levy D, Kuo AJ, Chang Y, Schaefer U, Kitson C, Cheung P, Espejo A, Zee BM, Liu CL, Tangsombatvisit S, et al. 2011. Lysine methylation of the NF- $\kappa$ B subunit RelA by SETD6 couples activity of the histone methyltransferase GLP at chromatin to tonic repression of NF- $\mathrm{kB}$ signaling. Nat Immunol 12: 29-36. doi:10.1038/ni.1968

Li G, Margueron R, Ku M, Chambon P, Bernstein BE, Reinberg D. 2010. Jarid2 and PRC2, partners in regulating gene expression. Genes Dev 24: 368-380. doi:10.1101/gad.1886410

Long Y, Bolanos B, Gong L, Liu W, Goodrich KJ, Yang X, Chen S, Gooding AR, Maegley KA, Gajiwala KS, et al. 2017a. Conserved RNA-binding specificity of polycomb repressive complex 2 is achieved by dispersed amino acid patches in EZH2. Elife 6: e31558. doi:10.7554/eLife.31558

Long Y, Wang X, Youmans DT, Cech TR. 2017b. How do lncRNAs regulate transcription? Sci $A d v$ 3: eaao2110. doi:10 $.1126 /$ sciadv.aao2110

Mazur PK, Reynoird N, Khatri P, Jansen PWTC, Wilkinson AW, Liu S, Barbash O, Van Aller GS, Huddleston M, Dhanak D, et al. 2014. SMYD3 links lysine methylation of MAP3K2 to Ras-driven cancer. Nature 510: 283-287. doi:10.1038/ nature 13320

McCabe MT, Ott HM, Ganji G, Korenchuk S, Thompson C, Van Aller GS, Liu Y, Graves AP, Della Pietra A III, Diaz E, et al. 2012. EZH2 inhibition as a therapeutic strategy for lymphoma with EZH2-activating mutations. Nature 492: 108-112. doi:10 $.1038 /$ nature 11606

Morey L, Helin K. 2010. Polycomb group protein-mediated repression of transcription. Trends Biochem Sci 35: 323-332. doi:10.1016/j.tibs.2010.02.009

Müller J, Hart CM, Francis NJ, Vargas ML, Sengupta A, Wild B, Miller EL, O'Connor MB, Kingston RE, Simon JA. 2002. Histone methyltransferase activity of a Drosophila Polycomb group repressor complex. Cell 111: 197-208. doi:10.1016/ S0092-8674(02)00976-5

Newton AC. 2003. Regulation of the ABC kinases by phosphorylation: protein kinase $\mathrm{C}$ as a paradigm. Biochem I 370: 361371. doi:10.1042/bj20021626

Paucek RD, Baltimore D, Li G. 2019. The cellular immunotherapy revolution: arming the immune system for precision therapy. Trends Immunol 40: 292-309. doi:10.1016/j.it.2019.02 .002

Piao L, Nakakido M, Suzuki T, Dohmae N, Nakamura Y, Hamamoto R. 2016. Automethylation of SUV39H2, an oncogenic histone lysine methyltransferase, regulates its binding affinity to substrate proteins. Oncotarget 7: 22846-22856.

Poepsel S, Kasinath V, Nogales E. 2018. Cryo-EM structures of PRC2 simultaneously engaged with two functionally distinct nucleosomes. Nat Struct Mol Biol 25: 154-162. doi:10.1038/ s41594-018-0023-y

Sampath SC, Marazzi I, Yap KL, Sampath SC, Krutchinsky AN, Mecklenbräuker I, Viale A, Rudensky E, Zhou M-M, Chait BT, et al. 2007. Methylation of a histone mimic within the histone methyltransferase G9a regulates protein complex assembly. Mol Cell 27: 596-608. doi:10.1016/j.molcel.2007.06.026

Sanulli S, Justin N, Teissandier A, Ancelin K, Portoso M, Caron M, Michaud A, Lombard B, da Rocha ST, Offer J, et al. 2015. 
PRC2 automethylation regulates histone methylation

Jarid2 methylation via the PRC2 complex regulates H3K27me3 deposition during cell differentiation. Mol Cell 57: 769-783. doi:10.1016/j.molcel.2014.12.020

Schmidt JC, Zaug AJ, Cech TR. 2016. Live cell imaging reveals the dynamics of telomerase recruitment to telomeres. Cell 166: 1188-1197.e9. doi:10.1016/j.cell.2016.07.033

Trievel RC, Beach BM, Dirk LMA, Houtz RL, Hurley JH. 2002. Structure and catalytic mechanism of a SET domain protein methyltransferase. Cell 111: 91-103. doi:10.1016/S00928674(02)01000-0

Wang X, Davidovich C. 2017. Targeting PRC2: RNA offers new opportunities. Oncotarget 8: 107346-107347.

Wang X, Goodrich KJ, Gooding AR, Naeem H, Archer S, Paucek RD, Youmans DT, Cech TR, Davidovich C. 2017a. Targeting of polycomb repressive complex 2 to RNA by short repeats of consecutive guanines. Mol Cell 65: 1056-1067.e5. doi:10 .1016/j.molcel.2017.02.003

Wang X, Paucek RD, Gooding AR, Brown ZZ, Ge EJ, Muir TW, Cech TR. 2017b. Molecular analysis of PRC2 recruitment to DNA in chromatin and its inhibition by RNA. Nat Struct Mol Biol 24: 1028-1038. doi:10.1038/nsmb.3487

Whitcomb SJ, Fierz B, McGinty RK, Holt M, Ito T, Muir TW, Allis CD. 2012. Histone monoubiquitylation position determines specificity and direction of enzymatic cross-talk with histone methyltransferases Dot1L and PRC2. J Biol Chem 287: 23718 23725. doi:10.1074/jbc.M112.361824

Wu H, Zeng H, Dong A, Li F, He H, Senisterra G, Seitova A, Duan S, Brown PJ, Vedadi M, et al. 2013. Structure of the catalytic domain of EZH2 reveals conformational plasticity in cofactor and substrate binding sites and explains oncogenic mutations. PLoS One 8: e83737. doi:10.1371/journal.pone.0083737

Yap DB, Chu J, Berg T, Schapira M, Cheng S-WG, Moradian A, Morin RD, Mungall AJ, Meissner B, Boyle M, et al. 2011. Somatic mutations at EZH2 Y641 act dominantly through a mechanism of selectively altered PRC2 catalytic activity, to increase H3K27 trimethylation. Blood 117: 2451-2459. doi:10.1182/blood-2010-11-321208

Youmans DT, Schmidt JC, Cech TR. 2018. Live-cell imaging reveals the dynamics of PRC2 and recruitment to chromatin by SUZ12-associated subunits. Genes Dev 32: 794-805. doi:10.1101/gad.311936.118

Zhang Q, McKenzie NJ, Warneford-Thomson R, Gail EH, Flanigan SF, Owen BM, Lauman R, Levina V, Garcia BA, Schittenhelm RB, et al. 2019. RNA exploits an exposed regulatory site to inhibit the enzymatic activity of PRC2. Nat Struct Mol Biol 26: 237-247. doi:10.1038/s41594-019-0197-y 


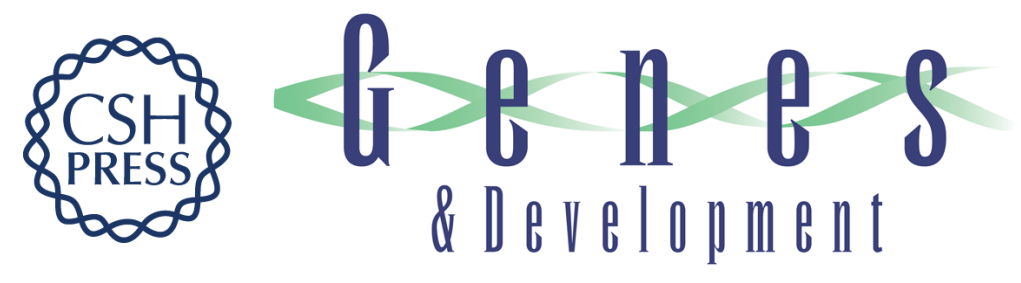

\title{
Regulation of histone methylation by automethylation of PRC2
}

\author{
Xueyin Wang, Yicheng Long, Richard D. Paucek, et al.
}

Genes Dev. 2019, 33: originally published online September 5, 2019

Access the most recent version at doi:10.1101/gad.328849.119

\section{Supplemental http://genesdev.cshlp.org/content/suppl/2019/09/04/gad.328849.119.DC1 \\ Material \\ Related Content \\ Automethylation of PRC2 promotes H3K27 methylation and is impaired in H3K27M pediatric glioma \\ Chul-Hwan Lee, Jia-Ray Yu, Jeffrey Granat, et al. \\ Genes Dev. October, 2019 33: 1428-1440 \\ References This article cites 45 articles, 19 of which can be accessed free at: \\ http://genesdev.cshlp.org/content/33/19-20/1416.full.html\#ref-list-1 \\ Articles cited in: \\ http://genesdev.cshlp.org/content/33/19-20/1416.full.html\#related-urls \\ Creative This article is distributed exclusively by Cold Spring Harbor Laboratory Press for the first Commons License six months after the full-issue publication date (see \\ http://genesdev.cshlp.org/site/misc/terms.xhtml). After six months, it is available under a Creative Commons License (Attribution-NonCommercial 4.0 International), as described at http://creativecommons.org/licenses/by-nc/4.0/. \\ Email Alerting
Service \\ Receive free email alerts when new articles cite this article - sign up in the box at the top right corner of the article or click here.}

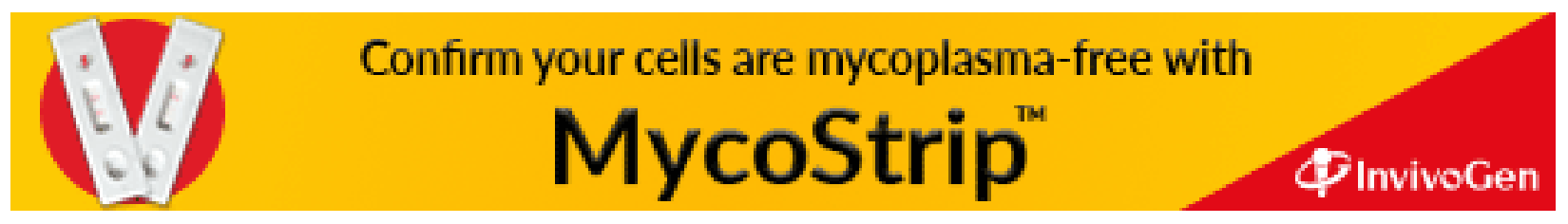

